\title{
Sexualitet som klassfråga
}

\author{
Rapport och intryck från konferensen Sexualität, Unterschichtenmilieus \\ und ArbeiterInnenbewegung, Internationale Tagung der \\ HistorikerInnen der Arbeiter- und anderer sozialer Bewegungen, Linz/ \\ Österrike, 13-15 september 2002
}

\author{
Av Marion Leffler, forskarassistent i historia, Växjö universitet
}

Länk till presentation av Marion Leffler

Internationale Tagung der HistorikerInnen der Arbeiter- und anderer sozialer Bewegungen, (ITH) bildades 1964 för att bereda arbetarhistoriker från väst och öst möjlighet att mötas en gång om året och presentera samt diskutera socialhistorisk forskning kring olika teman. Organisationen fungerar som paraplyorganisation för medlemsinstitutioner som finns i många länder världen över.[1]

Den ursprungliga målsättningen - att vara en bro mellan forskare från öst och väst med olika vetenskapskulturer - förändrades efter Berlinmurens fall och Sovjetunionens kollaps. Tidigare konferenser har handlat om den internationella arbetarrörelsens inställning till centrala politiska frågor, fackföreningsrörelsens historia och sociala och politiska förändringar efter de båda världskrigen. På 1980-talet kom socialhistoriska och kulturella frågor i förgrunden. Under 1990-talet har konferenserna haft ett implicit tema, nämligen "identiteter i förändring", utan att detta egentligen hade planerats. Bland dessa konferenser märks temat "Arbetarrörelsen - ett havererat modernitetsprojekt?".[2]

Temat för 2002 års konferens var sexualitet, ett ämne som hittills inte har varit framträdande i den arbetarhistoriska forskningen. Det var uppenbart att konferensens tema hade lockat nya deltagare[3], men kanske fătt andra som tidigare varit med på konferenserna att utebli. Det fanns dock en mindre grupp äldre deltagare, troligen tillhörande den tidigare kärnan i verksamheten, som ofta fällde kritiska kommentarer om de inlägg som inte föll inom ramen för en empiriskt orienterad historiematerialism, en tradition som dessa deltagare uppenbarligen föredrog. Denna spänning gjorde dock inte konferensen sämre utan stimulerade snarare till diskussioner och eftertanke. Sammanlagt presenterades under de två konferensdagarna 24 bidrag av forskare från Afrika, Asien, Nordamerika och Europa.

Konferensen öppnades med två teoretiskt orienterade bidrag. Paul Reynolds pläderade för en marxistisk sexualitetsforskning, dvs en forskning om hur våra sexuella identiteter konstrueras inom ramen för klass, kultur och konsumtion. Han föreföll vara närmast inspirerad av företrädare för den sk Frankfurtskolan, t ex Theodor W. Adorno och Jürgen Habermas. Elisabeth Holzleithner redogjorde engagerat för queerteorin, med vars hjälp man vill omformulera och omforma sexuella identiteter och genusidentiteter. Med ett sådant teoretiskt perspektiv betraktas varken kroppar eller identiteter som naturgivna men de anses inte heller helt och hållet stå till våra viljors förfogande. Med queerteorin kan man avgränsa och politisera de diskurser som konstruerar våra identiteter. Det som främst skilde dessa två inlägg åt var synen på klass som överordnad respektive inte överordnad andra identiteter. Queerteorin kom dock bort i diskussionen, som huvudsakligen kritiskt kommenterade Paul Reynolds version av marxism.

De återstående 22 bidragen var redovisningar av fallstudier.[4] På ett eller annat sätt berörde merparten frågor kring reproduktion, antingen genom att fokusera på 
arbetarfamiljernas strävan efter barnbegränsning genom preventivmedel, sexuella praktiker eller abort, eller genom att analysera reformatorers och politikers syn på dessa problem. Tolkningarna kunde vara diametralt motsatta. Jutta Schwarzkopf tecknade en mycket positiv bild av familjeplanering bland Lancashires bomullsvävare i slutet av 1800-talet. Eftersom män och kvinnor hade lika lön, lyckades dessa familjer anpassa familjeplaneringen till ekonomin, trots att detta krävde samarbete och självkontroll från männens sida. Anne-Marie Sohn tillskrev den franska arbetarklassen ett hedonistiskt förhållningssätt till sexualitet, vilket bl a innebar acceptans av ogifta mödrar och samboförhållanden från sekelskiftet och fram till 1950-talet. Först därefter ändrade arbetarklassen sin inställning till sexualiteten och kom att omfatta traditionella värderingar. Den progressiva rollen övertogs av studentrörelsen, menade hon. Stefan Bajohr fann däremot att arbetarfamiljer i Tyskland från sekelskiftet 1900 fram till 1933 intog en mycket restriktiv hållning, beroende på en påtaglig rädsla för könssjukdomar, med åtföljande ordlöshet och okunskap i sexuella frågor. Det var dock inte fråga om någon direkt sexualfientlighet, utan restriktionerna hade sin grund i den berättigade rädslan för sjukdomar. Försäljning av kondomer var fortfarande förbjuden. Britta McEwan redogjorde för hur socialdemokrater och andra samhällskrafter i det "röda Wien" under 1920-talet samverkade till att uppfostra mödrar i arbetarhem och deras barn. Medan kyrkan förmedlade traditionella värderingar ville socialdemokraterna skapa "den nya människan", som var behärskad och ansvarsfull. Gemensamt för dem var att de inte ifrågasatte könsrollerna och att kvinnans roll var och förblev moderns. Sexualitet förknippades alltså huvudsakligen med reproduktionen.

När det gäller inställningen till preventivmedel och abort, fann Karen Hunt och June Hannam att kvinnor inom The Independent Labour Party under 1920-talet betraktade preventivmedelsfrågan inte enbart som en klassfråga utan som en politisk angelägenhet och en del av det socialistiska projektet. I Sverige verkade Riksförbundet för sexuell upplysning (RFSU) för rätten till abort och sterilisering under 1930- och 1940-talen. Frågorna drevs till en början i politiskt syfte, för att medverka till samhällsförändring och utifrån ett klassperspektiv. Efterhand professionaliserades organisationen och blev en del av det etablerade samhället. Det politiska perspektivet ersattes av ett medicinskt och psykologiskt, och klassperspektivet ersattes av ett individperspektiv, enligt Lena Lennerhed. Cornelie Usborne framhöll att populärkulturen i Weimarrepubliken sände tvetydiga budskap i sina skildringar av aborter. Å ena sidan konstruerades bilden av den utsläpade arbetarkvinnan som riskerade liv och lem i illegala aborter, å andra sidan tolkades kvinnokroppen i termer av modernitet, sexuell frigörelse och självbestämmande i fråga om reproduktion. Gemensamt var dock att aborter i dessa skildringar alltid utfördes av farliga kvacksalvare och betraktades som tragedier. Dessa skildringar stämmer inte överens med arbetarkvinnornas egna berättelser. Här uppfattades aborter ofta som utförda av en hjälpande vän och som positiva erfarenheter.

Ruth Gutermann redogjorde för sin forskning om den anarkistiska pressen i Spanien åren 1923-1937. Här förespråkades familjeplanering och eugenik. Moderskapet skulle vara medvetet - däri låg den nya moralen. Reproduktionen var dock kvinnans ansvar. Anarkisterna präglades av en stark tro på vetenskapens förmåga att förbättra människan samtidigt som de uppvisade en omedvetenhet om makt.

Arbetarklassen tillskrevs således såväl en hedonistisk som en restriktiv hållning till sexualitet. Med upplysningskampanjer och krav på rättighet till abort och preventivmedel politiserades reproduktionsfrågor på olika sätt i olika länder, dock alltid med förutsättningen att reproduktionen var kvinnans ansvar. De traditionella genusrelationerna ifrågasattes alltså inte av arbetarrörelserna i de olika länderna.

Några bidrag behandlade statlig familje- och sexualpolitik, främst i tidigare kommunistiskt styrda länder. Anelia Kassabova-Dintcheva tolkade den bulgariska statens politik fram till kommunismens fall som repressiv. Barnbidrag och glorifiering av moderskapet var ett sätt att få en befolkningsökning, dock på bekostnad av de etniska minoriteterna.

Familjepolitiken syftade till att stabilisera den kommunistiska nationalstaten. Ljubov 
Kusnetsova menade att sexualpolitiken i Ryssland under 1920-talet inte ledde till en ny moral, utan till normlöshet, medan 1930-talets politik förtryckte varje form av individuell frihet och syftade till att kanalisera arbetarnas sexuella energi till produktionen. Denna slutsats problematiserades av Berthold Unfried, som beskrev den praktik som var vanlig vid partisammankomster i Ryssland under 1930-talet. Medlemmarna skulle här öva kritik och självkritik, bl a i frågor om sexualitet. Kritik utövades mot män som inte behandlade kvinnor som kamrater utan som objekt, som negligerade familjen, som visade ett avvikande sexuellt beteende etc.

Politiken kunde alltså syfta till att stabilisera nationalstaten, att kanalisera arbetarnas sexuella energi till produktionen, eller att genom uppmuntran till självkritik reglera arbetarnas sexuella beteenden.

Narges Erami upplyste om en för många troligen oväntad politik i det post-revolutionära Iran. Här sanktioneras tillfälliga "äktenskap" - så pass korta som endast en natt - av religiösa ledare. Syftet är att undvika att ungdomar och änkor hemfaller åt promiskuitet, vilket är en svår synd. Tillfälliga "äktenskap" är alltså inte tecken på upplösning av de religiösa normerna utan snarare ett sätt att bevara dem. Man ger efter för människors sexuella behov för att kunna bibehålla dödsstraff för prostitution och äktenskapsbrott.

Arbetarklassens, och då främst unga arbetarkvinnors, sexuella beteende har ofta varit ett bekymmer för medelklassen, vilket två konferensbidrag visade. I sekelskiftets USA skapade kvinnliga socialarbetare av omsorg om arbetarklassens unga kvinnor alternativa dansställen med vuxen övervakning, alkoholfria drycker och lämpliga dansstilar. Önskan att skydda de unga kvinnorna är svår att skilja från viljan att kontrollera deras sexuella beteende, menade Elisabeth Perry. I Kanada internerades i mitten av 1900-talet såväl vita unga kvinnor som unga kvinnor tillhörande ursprungsbefolkningen i

ungdomsvårdsanstalter. Promiskuitet var den vanliga anledningen, även om kvinnorna hade häktats för andra förseelser. På anstalten skulle de bli "arbetande kroppar" i stället för "sexuella kroppar". De tränades i husligt arbete och anpassades till rådande strukturer av genus-, klass- och rasskillnader, enligt Joan Sangster.

Manligt sexuellt beteende beskrevs främst i den forskning som hade sexuella trakasserier på arbetsplatser som studieobjekt. Stephen Meyer fann att kvinnor i den amerikanska bilindustrin trakasserades sexuellt av manliga arbetskamrater och förmän såväl under 1930talet som under efterkrigstiden. Under krigstiden minskade trakasserierna, framför allt eftersom många kvinnor som arbetade under dessa år var släkt med de manliga anställda. När kvinnor ses som konkurrenter ökar trakasseringen. Fackföreningsrörelsens manliga kultur hindrar effektiva motåtgärder.

I Kina uppger en majoritet av kvinnliga anställda i framför allt privata företag att de utsätts för sexuella trakasserier, inte minst av cheferna. Frånvaro av lagstiftning och den kinesiska traditionen med inslag av kvinnoförtryck samt rädsla att förlora arbetet gör dock att få kvinnor för fram klagomål. Detta bidrag, av Minjie Zhang, utmynnade i en politisk appell att införa lagstiftning mot sexuella trakasserier i Kina och att vara vaksam mot privatiseringens problem.

Raja Gopal Dhar Chakraborti beskrev manligt sexuellt riskbeteende bland arbetarna i juteindustrin i Indien. Majoriteten är arbetsvandrare utan regelbunden kontakt med sina familjer. De söker sig ofta till prostituerade, samtidigt som deras kunskaper om preventivmedel och sexuellt överförbara sjukdomar är ringa. Även detta bidrag slutade i en appell till arbetsgivarna att upplysa arbetarna och anbefalla avhållsamhet. Såväl det kinesiska som det indiska bidraget hade alltså ett uttalat instrumentellt och politiskt syfte.

Tre bidrag handlade om prostitution i olika former. I Egypten förekommer s k "urfi marriages", en form av prostitution som innebär att unga egyptiska män i turistområdet Dahab ingår icke legaliserade äktenskap med turistande kvinnor från västvärlden, fick vi veta av Mustafa Abdel Rahman. Det är underförstått att kvinnan står för försörjningen i 
utbyte mot sex så länge "äktenskapet" varar. Genusrelationen är här komplex - den utländska kvinnan är privilegierad på grund av sin klasstillhörighet och status men samtidigt utsatt för den egyptiska patriarkalismen. Manlig prostitution förekommer också bland afro-kubaner, som skapar sig en identitet som homosexuella "sex workers" genom att utmana den (vita) hegemoniska maskuliniteten, enligt Jafari Sinclaire Allen. Tyvärr blev detta bidrag kraftigt beskuret på grund av tidsbrist. P Swarnalatha beskrev hur de "dancing girls" som i det traditionella indiska samhället haft en aktad position som mäktiga mäns älskarinnor under kolonialismens inflytande omdefinierades till simpla prostituerade.

Dessa tre bidrag ville nyansera den vanligen negativa synen på prostitution och ersätta begreppet prostituerade med sexarbetare. Det kan framhållas att det här handlade om manliga prostituerade i icke-europeiska sammanhang respektive om indiska kvinnor vars status hade definierats som prostituerad först under kolonialismens tid. Nedvärderingen av prostituerade sammanfaller alltså med kolonialt och post-kolonialt förtryck. I denna kontext förefaller viljan att förändra synen på de prostituerade som rimlig men frågan är om man inte på ett tydligare sätt borde visa på sambandet mellan sexuellt beteende och koloniala förhållanden än vad dessa bidrag gjorde. Prostitutionens innebörd är rimligen olika i de koloniserande respektive de koloniserade länderna.

Forskning om homosexualitet hade en undanskymd plats på konferensen. Med tanke på att denna forskning har fört upp frågor om sexualitet på dagordningen i många länder och inte minst - har stått för utvecklingen av queerteorin är detta anmärkningsvärt.[5] Endast två av de tjugotvå bidragen behandlade frågor om homosexualitetens betydelse i olika sammanhang, och de utgick inte från queerteorin. David Berry presenterade en biografi över Daniel Guérin som han arbetar med. Guérin var både socialist och homosexuell i en homofobisk arbetarrörelse. På 1950-talet började han propagera mot förtrycket av homosexualiteten och drog senare paralleller mellan detta förtryck och förtrycket av de svarta i USA och av de koloniserade folken. Lösningen för alla dessa var "en antiauktoritär revolution". Jon Binnie och Beverly Skeggs visade hur Manchesters gaydistrikt utnyttjas av heterosexuella från medelklassen för att dessa skall kunna definiera sig själva som toleranta kosmopoliter. De menade att de homosexuellas egna utrymmen invaderas och begränsas. Det blir därför svårt att utveckla gaykulturen.

Som framgår hade konferensen en ämnesmässig och internationell bredd, samtidigt som de flesta bidragen i grund och botten kretsade kring reproduktion och därmed sammanhängande problem. Huruvida den också speglade ett aktuellt forskningsfält är osäkert. Å andra sidan fokuserade konferensen på klass och sexualitet, något som inte är vanligt inom det dominerande forskningsfältet. Sexualitetsforskningen har i huvudsak bortsett från frågor om klasstillhörighetens betydelse eller betraktat klass som underordnad andra identiteter.[6] Vi saknar kunskap om samspelet mellan sociala processer och formeringen av sexuella identiteter. Konferensen i Linz visade att klassbegreppet är en fruktbar utgångspunkt för studier av sexualitet, och jag hoppas att den har inspirerat många deltagare till vidare forskning på temat.

\section{(C) Marion Leffler}

[1] För mera detaljerade uppgifter om organisationen, se ITH. Die ITH und ihre "Linzer Konferenzen. The ITH and its "Linz Conferences". Wien 1994. Aktuell medlemsförteckning, se http://www.ith.or.at/ith/mitglieder.htm

[2] Die ITH und ihre "Linzer Konferenzen", s. 31-42

[3] Många deltagare jag talade med var där för första gången och hade inte tidigare hört talas om ITH och Linzkonferenserna.

[4] Konferensen var strukturerad kring sju olika delteman som dock överlappade varandra.

För en mera utförlig presentation av enskilda bidrag, se www.ith.or.at

[5] Se t ex Sex and Conflict. Dokumentation från konferensen vid Lunds universitet 9-10 oktober 1998

[6] Se exemplen i Sex and Conflict. 